\title{
In-Vitro Antiproliferative Analysis of Metformin Hydrochloride on Androgen-Sensitive, LNCAP and Androgen-Insensitive, PC-3 Human Prostate Cancer Cell Lines
}

\author{
Brittney V. Hinton, Dolapo A. Adedeji*, Gloria E. Payne \\ Dr. Herman G. Cooke Department of Natural Sciences, Pharmacy \& Health Professions, Elizabeth City State University, Elizabeth \\ City, NC, USA \\ Email: *daadedeji@ecsu.edu
}

How to cite this paper: Hinton, B.V., Adedeji, D.A. and Payne, G.E. (2017) InVitro Antiproliferative Analysis of Metformin Hydrochloride on Androgen-Sensitive, LNCAP and Androgen-Insensitive, PC-3 Human Prostate Cancer Cell Lines. Pharmacology \& Pharmacy, 8, 85-89. https://doi.org/10.4236/pp.2017.83006

Received: February 8, 2017

Accepted: March 28, 2017

Published: March 31, 2017

Copyright $\odot 2017$ by authors and Scientific Research Publishing Inc. This work is licensed under the Creative Commons Attribution International License (CC BY 4.0).

http://creativecommons.org/licenses/by/4.0/

\begin{abstract}
Prostate cancer is one of the diseases worldwide that causes cancer-related deaths in men. Metformin is an antidiabetic drug that has been in use for over two decades for the treatment of Type II Diabetes mellitus (DM2). The purpose of this study was to evaluate the anti-proliferative property of metformin hydrochloride on androgen-sensitive, LNCAP and androgen-insensitive, PC-3 human prostate cancer cell lines at different concentrations ( $\mu \mathrm{M}$ and $\mathrm{mM})$ using 3-[4,5-dimethylthiazol-2-yl]-2,5-diphenyltetrazolium bromide (MTT) assay. Metformin hydrochloride displayed a stronger cytotoxicity on the androgen-insensitive PC-3 than on the androgen-sensitive human prostate cancer cell lines. For both cell lines, the antiproliferative activity of metformin hydrochloride was best displayed at $0.1 \mathrm{mM}$ concentration with average cell death percentage of $60 \%$ after 120 -hour exposure.
\end{abstract}

\section{Keywords}

Metformin Hydrochloride, Prostate Cancer, Type II Diabetes Mellitus (DM2)

\section{Introduction}

Prostate cancer is one of the foremost diseases worldwide that causes cancer-related deaths in men. It is the second most common noncutaneous cancer that affects thousands of men each year in the United States and occurs in older men above the age of 65 years. Every year, 20.7 per 100,000 men per year die of prostate cancer and one out of nine men is diagnosed with prostate cancer. It was estimated that $26,120(4.4 \%)$ with prostate cancer will die in 2016 out of 180,890 new cases diagnosed [1]. Type II diabetes mellitus (DM2) is a common disease 
that affects about $9.3 \%$ ( 29 million) of people aged 20 years or older in the United States [2] [3]. Metformin, which belongs to the biguanide family, has been used for over two decades as the first line oral therapy for DM2 due to its clinical efficacy and low toxicity profile. The drug suppresses the hepatic glucose production through a mild and transient inhibition of the mitochondrial respiratory chain complex I [4]. This leads to the activation of AMPK (AMP-activated protein kinase). This effect has been suggested that metformin inhibits cancer cell proliferation and induces apoptosis by decreasing the energy disposition due to AMP: ATP ratio elevation and AMPK activation which can suppress tumor formation [5]. Different epidemiology studies have suggested that there is a decrease in the incidence and mortality rate of different cancers with the use of metformin. Case-control studies revealed that new users of metformin have a low risk of developing cancer [6] [7] [8] [9]. In this study, we describe findings supporting the antiproliferative property of metformin hydrochloride on human prostate cancer cell lines, LNCaP and PC-3.

\section{Method}

\section{In Vitro Antiproliferative Assay}

The MTT Cell Proliferation Assay was used in assessing the cytotoxicity profile of metformin hydrochloride. Cell lines, Prostate adenocarcinoma; (Homo sapiens) - PC-3 and LNCaP, purchased from American Type Culture Collection (ATCC) were cultured and maintained in RPMI 1640 medium containing 10\% FBS, penicillin-streptomycin, sodium pyruvate, glutamine and non-essential amino acids at $37^{\circ} \mathrm{C}$ in $5 \% \mathrm{CO}_{2}$ humidified environment. Cell lines were harvested upon confluency, and then seeded into 96-well plates (with the exception of a two rows designated for a blank and vehicular control). The PC- 3 cells were seeded at densities between $0.75 \times 10^{4}$ and $1.5 \times 10^{4}$ cells per well while the LNCaP was seeded at a density of $2.0 \times 10^{4}$. Cells were given 24 hours to attach to the wells. Proceeding the 24-hour incubation period, the RPMI medium was aspirated and replaced with $100 \mu \mathrm{L}$ of the metformin hydrochloride in either fresh medium or DMSO. Metformin hydrochloride concentrations used were 3 $\mu \mathrm{M}, 5 \mu \mathrm{M}, 8 \mu \mathrm{M}, 0.1 \mathrm{mM}, 3 \mathrm{mM}, 5 \mathrm{mM}$, and $8 \mathrm{mM}$. The blank row contained wells of cells within the required density ranges, and the control row contained cells within the density ranges and $100 \mu \mathrm{L}$ of $0.001 \%$ DMSO. Five replicates of each concentration, in addition to the blank and control, were run in parallel. Viability of the cells was determined quantitatively by treatment with the reducing agent 3-[4,5-dimethylthiazol-2-yl]-2,5-diphenyltetrazolium bromide (MTT). A MultiSkan FT spectrophotometer was used in determining the optical densities of the solutions of the resulting formazan products for each assay. The MTT assays were performed after 72-hour and 120-hour exposure of each cell line to each concentration of the drug. $10 \mu \mathrm{L}$ of MTT reagent was added to each well at the end of the 72-hour and 120-hour incubation periods, and the plate(s) were returned to the humidified environment for 2 to 4 hours or until a purple dye is visible. When the purple precipitate is clearly visible under an inverted micro- 
scope, $100 \mu \mathrm{L}$ of Detergent Reagent was added to all wells. Cell viability was determined by comparing the optical density (OD) of the treated versus the control (Corrected OD of the treated/Corrected OD of control $\times 100 \%$ ) [10].

\section{Results and Discussion}

Antiproliferation activity using MTT assay was used to determine the anticancer activity of metformin hydrochloride, an antidiabetic drug. The results indicated that the activity of metformin hydrochloride uses both dose-and time-dependents cytotoxicity (Figure 1).

The average cell death ranging between $20 \%$ and $60 \%$ was observed when androgen-dependent, LNCaP, and androgen-independent, PC-3, human prostate cancer cell lines were treated with metformin hydrochloride at different concentrations of $3 \mu \mathrm{M}, 5 \mu \mathrm{M}, 8 \mu \mathrm{M}, 0.1 \mathrm{mM}, 3 \mathrm{mM}, 5 \mathrm{mM}$, and $8 \mathrm{mM}$. In PC-3 cell line, the average cell death percentage was between $21 \%$ and $33 \%$ at $\mu \mathrm{M}$ concentrations at 72- and 120-hour exposure respectively. The average cell death percentage increases to $53 \%$ and $57 \%$ after 72 - and 120 -hour exposure respectively at $\mathrm{mM}$ concentrations. In LNCaP cell line, the average cell death percentage did not change $(25 \%)$ at $\mu \mathrm{M}$ concentrations at both 72 - and 120 -hr exposure. The same trend was observed at $\mathrm{mM}$ concentrations. The average cell death percentage did not change at 72 -hour exposure $(\sim 47 \%)$ and about $49 \%$ was observed after 120-hour exposure of the cell line to metformin hydrochloride.

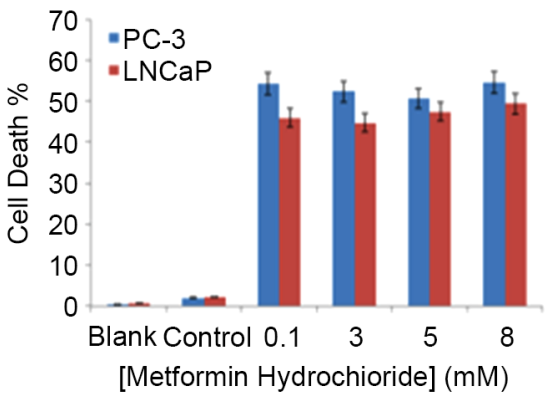

(a)

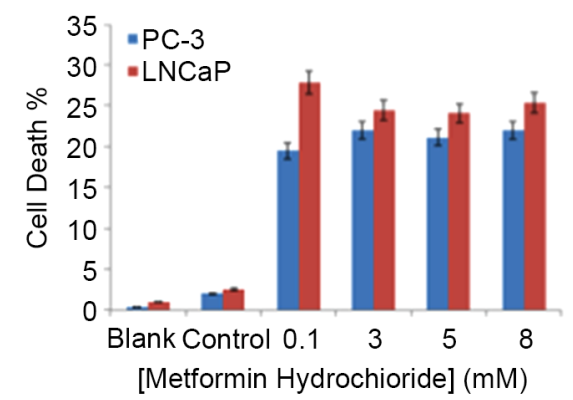

(c)

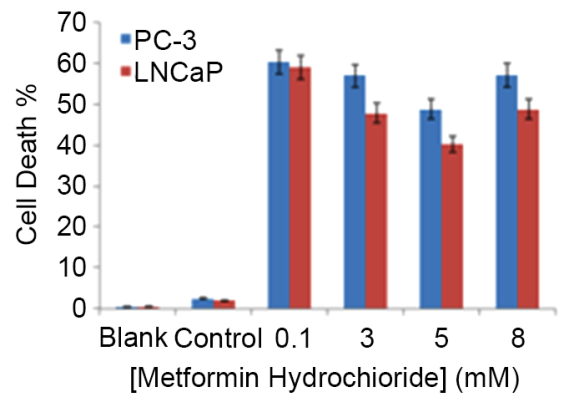

(b)

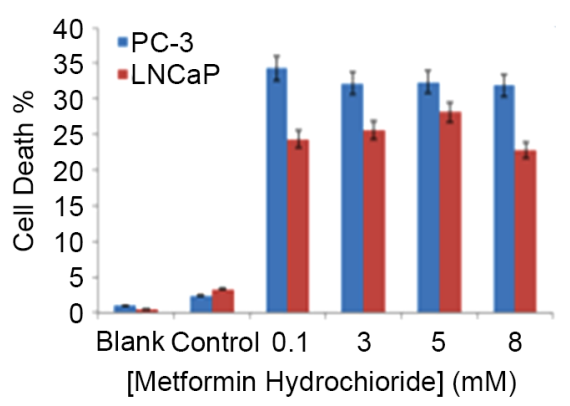

(d)

Figure 1. Average cytotoxic effects of metformin hydrochloride on human prostate cancer cell lines. The cancer cell lines were treated with $0.001 \%$ DMSO (control). (a) Cell death percentage with metformin at $\mathrm{mM}$ concentrations after 72 hours of incubation, (b) metformin at $\mathrm{mM}$ concentrations after 120 hours of incubation, (c) metformin at $\mu \mathrm{M}$ concentrations after 72 hours of incubation and (d) metformin at $\mu \mathrm{M}$ concentrations after 120 hours of incubation. 
The result of this study showed that metformin hydrochloride displayed cytotoxicity to some extent regardless of whether the prostate cancer cell line is androgen-sensitive or androgen-insensitive after 72 and 120-hour exposure. A stronger effect was observed on the androgen-insensitive (PC-3) than on the androgen-sensitive (LNCaP) prostate cancer cell lines. This finding also indicates that additional experiments using combination studies with chemotherapeutic agents like doxorubicin and cisplatin [11] [12] need to be performed to evaluate the potential strategy to treat prostate cancer patients with DM2. Although, more studies have to be done on mice having prostate cancer and treating them with metformin and chemotherapeutic agents mentioned above. This would be the first step before clinical trials can commence. Therefore, for elderly males diagnosed with diabetes and prostate cancer, metformin may aid in suppressing the cancer growth by serving as a defense mechanism for DM2; thereby reducing the cancer mortality rates in obese men.

\section{Grant Support}

This study was supported by a grant from the Master's Degree Programs at Historically Black Colleges and Universities (MD-HBCU). Grant Award Number: P382G090002

\section{References}

[1] Surveillance, Epidemiology, and End Results Program (SEER 2016). National Cancer Institute, NIH.

[2] Stefansson, E. and Einarsdóttir, A. (2015) Public Health and Prevention of Blindness in Diabetes. International Journal of Diabetes Mellitus, 3, 1-3.

https://doi.org/10.1016/j.ijdm.2011.01.011

[3] Azoulay, L., Dell'Aniello, S. Gagnon, B., et al. (2010) Metformin and Incidence of Prostate Cancer Patients with Type 2 Diabetes. Cancer Epidemiology, Biomarkers \& Prevention, 20, 337-344. https://doi.org/10.1158/1055-9965.EPI-10-0940

[4] Viollet, B., Guigass, B., et al. (2012) Cellular and Molecular Mechanisms of Metformin: An Overview. Clinical Science, 122, 253-270.

https://doi.org/10.1042/CS20110386

[5] Salani, B., Del Rio, A., Marini, C., et al. (2014) Metformin, Cancer and Glucose Metabolism. Endocrine-Related Cancer, 21, R461-R471. https://doi.org/10.1530/ERC-14-0284

[6] Evans, J.M., Donnelly, L.A., et al. (2009) Metformin and Reduced Risk of Cancer in Diabetic Patients. British Medical Journal, 32, 1620-1625.

[7] Wright, J.L. and Stanford, J.L. (2009) Metformin Use and Prostate Cancer in Caucasian Men: Results from a Population-Based Case-Control Study. Cancer Causes Control, 20, 1617-1622. https://doi.org/10.1007/s10552-009-9407-y

[8] He, X.-X, Tu, S.M., Lee, M.-H. and Yeung, S.-C.J. (2011) Thiazolidinediones and Metformin Associated with Improved Survival of Diabetic Prostate Cancer Patients. Annals of Oncology, 22, 2640-2645. https://doi.org/10.1093/annonc/mdr020

[9] Libby, G., Donnelly, L.A., Donnan, P.T., et al. (2009) New Users of Metformin Are at Low Risk of Incident Cancer: A Cohort Study among People with Type 2 Diabetes. Diabetes Care, 32, 1620-1625. https://doi.org/10.2337/dc08-2175 
[10] Brandy, Y., Ononiwu, I., Adedeji, D., et al. (2011) Synthesis and Cytotoxic Activities of So, Me 2-Arylnaphtho [2.3-d] oxazole-4,9-dione Derivatives on Androgen-Dependent (LNCaP) and Androgen-Independent (PC-3) Human Prostate Cancer Cell Lines. Investigational New Drugs, 30, 1709-1714. https://doi.org/10.1007/s10637-011-9635-3

[11] Singal, P.K. and Iliscovic, N. (1998) Doxorubicin-Induced Cardiomyopathy. NEJM, 339, 900-905. https://doi.org/10.1056/NEJM199809243391307

[12] Siddik, Z.H. (2003) Cisplatin: Mode of Cytotoxic Action and Molecular Basis of Resistance. Oncogene, 22, 7265-7279. https://doi.org/10.1038/sj.onc.1206933

\section{Scientific Research Publishing}

Submit or recommend next manuscript to SCIRP and we will provide best service for you:

Accepting pre-submission inquiries through Email, Facebook, LinkedIn, Twitter, etc. A wide selection of journals (inclusive of 9 subjects, more than 200 journals) Providing 24-hour high-quality service User-friendly online submission system Fair and swift peer-review system Efficient typesetting and proofreading procedure Display of the result of downloads and visits, as well as the number of cited articles Maximum dissemination of your research work

Submit your manuscript at: http://papersubmission.scirp.org/

Or contact pp@scirp.org 